\title{
Targeted action and molecular interactions of sarcin and thionin with aspergillosis causing Aspergillus fumigatus
}

\author{
Ramya Ravindhiran', Ramya Krishnamurthy', Karthiga Sivarajan'1, Jothi Nayaki Sekar', Kumarappan Chidam- \\ baram $^{2}$, Kavitha Dhandapani ${ }^{1, *}$
}

\begin{abstract}
${ }^{1}$ Department of Biochemistry, Biotechnology and Bioinformatics, Avinashilingam Institute for Home Science and Higher Education for Women, Coimbatore-641 043, Tamil Nadu, India.

${ }^{2}$ Department of Pharmacology \& Toxicology, School of Pharmacy, King Khalid University, Abha 62529, Saudi Arabia.

* Correspondence: kavitha bio@avinuty.ac.in
\end{abstract}

Abstract : Fungal infections are more predominant in agricultural and clinical fields. Aspergillosis caused by Aspergillus fumigatus leads to respiratory failure in patients along with various illnesses. Due to the limitation of antifungal therapy and antifungal drugs, there is an emergence to develop efficient antifungal compounds from natural sources to cure and prevent fungal infections. The present study deals with the investigation of the mechanism of active compounds from our candidate agonist Aspergillus giganteus for aspergillosis. The integrity of treated Aspergillus fumigatus cell membrane and nuclear membrane was analyzed by determining the release of cellular materials. The antagonistic potential of antifungal compounds on the pathogen was confirmed by SEM analysis. The effective concentration of antifungal compounds (AFCs) was found to be $250 \mu \mathrm{g} / \mathrm{ml}$. The GC-MS profiling has revealed the bioactive metabolites responsible for the antagonistic nature of Aspergillus giganteus. The bioavailability and toxicological properties of pathogenesis related proteins have proved the efficiency of pharmacokinetic properties of selected compounds. Interaction of sarcin, thionin, chitinase and its derivatives from Aspergillus giganteus with the virulence proteins of UDP-N-acetylglucosamine pyrophosphorylase, $\mathrm{N}$-myristoyl transferase and Chitinase have proved the druggable nature of the antifungal compounds.

Keywords: Aspergillus giganteus; Aspergillosis; Antagonism; Sarcin; ADMET; GC-MS

\section{Introduction}

Emergence of fungal infection has tremendously increased in the past three decades worldwide [1]. Infectious diseases caused by fungi develop a resistance mechanism against existing antibiotics [2]. Most of the pathogenic fungi are polymorphic and can undergo reversible morphological transitions between yeasts in both pseudohyphal and hyphal growth forms [3]. Despite the emergence of invasive fungal infections, therapies mainly rely upon the use of antifungal drugs from synthetic sources namely, Amphotericin B, Azole antifungal compounds, Echinocandins [4]. Most of these drugs are currently used in clinical practices. Unfortunately, the antifungal drugs may interact with other medications and possibly cause side effects, resistance problems, and most of them are fungistatic rather than fungicidal and some of them are often toxic to the patients. These antifungal drugs inhibit a target unique to fungi and they show good therapeutic ratios but their oral bioavailability is considerably low $[5,6]$.

Aspergillus fumigatus, aspergillosis causing fungal pathogen, is a life-threatening severe infection provoked by the inhalation of spores and conidia, especially in 
immunocompromised patients affected by AIDS, organ transplantation or patients who have a long term invasive medical practices and posing a big threat to human health. One kind of alkaloid in A. fumigatus represented as ergot alkaloids were found to cause severe health deteriorating problems in both human and animals [6-8]. Apart from causing infections in the host, its pathogenic potential extended towards asthma and leads to other allergic complications in humans and animals. Aspergillus genus was found ubiquitously and have distributed in a wide range of different climatic conditions with pathogenic potential [9]. Aspergillus fumigatus cell wall composition relies on the stage of the pathogenic progression in the host, hence the immune system of the host also get varies on its action [10,11].

Fungi have been considered as an optimal source, producing active metabolites in terms of primary and secondary natural metabolic bioactive components. These compounds are differentiated by their structures and functions [12]. Aspergillus giganteus is known to produce small, basic and cysteine-rich antimicrobial compounds that are proved to have maximum antagonistic activity against the number of filamentous fungi. The antifungal protein (AFP) consists of 51 amino acids and it remains inactive in its prosequence form with 91 amino acids that are cleaved by the action of proteases during the secretion process [13]. The exact mechanism of action of AFP is still not explained well. The active metabolite perturbs the plasma membrane of the host cell and subsequently, the synthesis of chitin in filamentous fungi also gets suppressed [14]. In this regard, it might get invading into the pathogenic cell and interact with the nucleic acids of fungi results in the release of nuclear contents [15]. Several studies have shown that AFP and its mechanism of action differed from species to species. It involves either forming a pore on the host cell membrane or inhibit cell wall synthesis and intruding with nucleic acids \& their synthesis or inhibiting the protein synthesis thereby interfering with the control of the cell cycle [16].

In vitro and in vivo studies have proved that Aspergillus giganteus could be used as a biocontrol agent to inhibit other fungal growth that leads to crop destructions [17-19]. Apart from agricultural purposes, it can be identified as an antifungal compound for the treatment of various fungal infections in humans especially caused by Candida albicans, Aspergillus oryzae, Aspergillus niger, Fusarium oxysporum and Botrytis cinerea [20-22]. Hence, the present study aimed to investigate the mode of targeted action of antifungal compounds for the inhibition of fungal strains that causes aspergillosis.

\section{Results}

The culture filtrates were prepared to examine the mechanism of action of AFCs on the pathogenic cell wall and cell membrane. The AFCs are extracellular and protein in nature. The protein concentrations were estimated in the supernatant (culture filtrates) and it was found to be $0.75 \mathrm{mg} / \mathrm{ml}$.

\subsection{Scanning Electron Microscopic analysis}

Morphological changes of pathogenic fungi treated with antagonistic fungi were well established by Scanning Electron Microscopy Figure 1 A\&B. Extensive damage and collapsed structure with hyphal distortion to the Aspergillus fumigatus was 
noticed in plates treated with AFCs of Aspergillus giganteus. In control plates, regular-shaped homogenous hyphae were observed and it was confirmed under different resolutions.

\section{A) $10 \mu \mathrm{m}$ resolution}

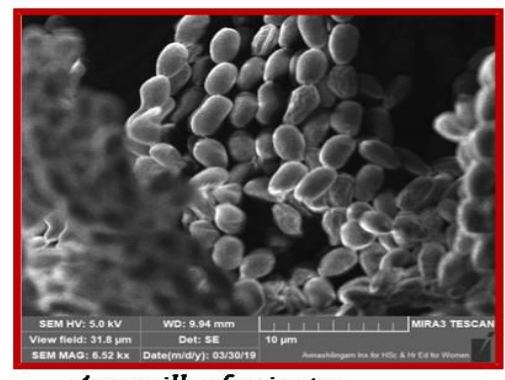

Aspergillus fumigatus

B) $2 \mu \mathrm{m}$ resolution

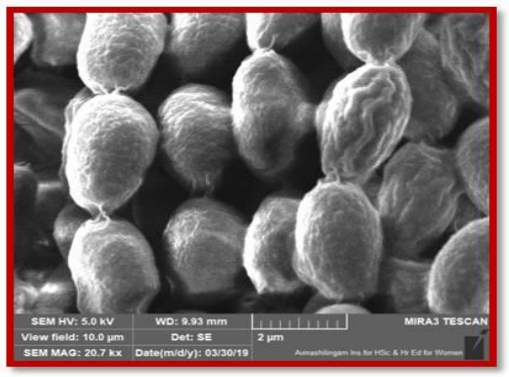

Aspergillus fumigatus

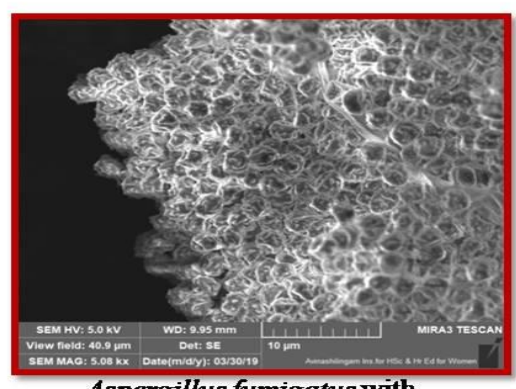

Aspergillus fumigatus with

Aspergillus giganteus

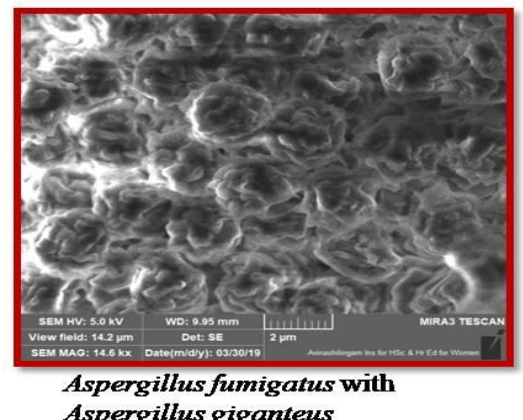

Aspergillus giganteus

Figure. 1A\&B: Scanning Electron Microscopic images of control and AFCs of Aspergillus giganteus treated Aspergillus fumigatus

\subsection{Antifungal mechanisms}

2.2.1. Cell membrane integrity assay of AFCs on pathogenic cell

Cell membrane integrity assay was performed to investigate the mechanistic action of AFCs in the culture filtrates of Aspergillus giganteus on the pathogenic cell membrane, Aspergillus fumigatus.

\subsubsection{Release of nucleic acids}

The released materials such as DNA and RNA were used to analyse the effects of AFCs on the pathogenic cell membrane by measuring the absorbance at $260 \mathrm{~nm}$. The released DNA content by the action of AFCs was depicted in Figure 2A and the release of DNA into the medium was observed maximum at 120 minutes of exposure of AFCs on pathogenic cellular membrane. The $\mathrm{OD}_{260}$ values were noted as $0.05 \pm 0.01,0.10 \pm 0.01$, $0.18 \pm 0.02,0.22 \pm 0.02$ and $0.40 \pm 0.03$ for the concentration of AFCs 50, 100, 150, 200 and $250 \mu \mathrm{g}$, respectively. As clearly stated that increased concentration of AFCs in Aspergillus giganteus may disturb the cellular membrane of Aspergillus fumigatus, thus causes the genetic material to get released into the medium.

AFCs in the culture filtrates also targets RNA, another important genetic material. Fig. $2 \mathrm{~B}$ shows the results of cell membrane integrity assay for the release of RNA components. Maximum leakage of RNA components was noted at 120 mins of 
treated pathogenic strain with the concentration of AFCs with the range of 50, 100, 150, 200 and $250 \mu \mathrm{g}$, and the amount of released constituents was observed as $75 \pm 0.01 \mu \mathrm{g} / \mathrm{ml}$, $141.6 \pm 0.01 \mu \mathrm{g} / \mathrm{ml}, 158.3 \pm 0.02 \mu \mathrm{g} / \mathrm{ml}, 198.7 \pm 0.02 \mu \mathrm{g} / \mathrm{ml}$ and $258.3 \pm 0.01 \mu \mathrm{g} / \mathrm{ml}$, respectively. The AFCs in the culture filtrates of Aspergillus giganteus proved to be an effective tool to disrupt and damage the pathogenic fungal cell membrane.
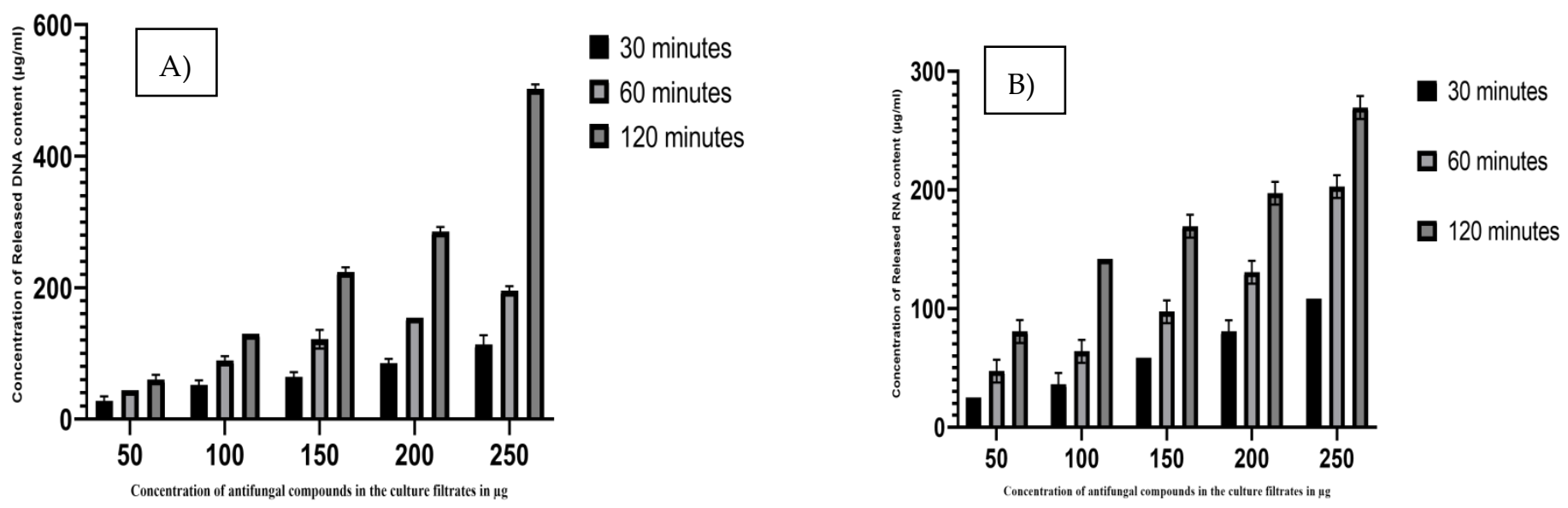

Figure 2. Release of DNA (Fig. 2A) \& RNA (Fig. 2B) from cell membrane of Aspergillus fumigatus treated with different concentrations of AFCs of Aspergillus giganteus. The results are expressed as $\mu \mathrm{g} / \mathrm{ml}$ of components released. Data are represented as mean $\pm \operatorname{SD}(\mathrm{n}=3)$

\subsubsection{Leakage of proteins and glucose}

The amount of released protein and glucose were measured by their absorbance at $670 \mathrm{~nm}$ and $630 \mathrm{~nm}$, respectively. Figure 3 shows the action of AFCs on the pathogenic cell membrane by estimating the released protein and glucose contents. It explains that the release of cellular compounds has increased in a concentration-time-dependent manner.

The enhancement of released protein contents was observed in the treated Aspergillus fumigatus with AFCs (50, 100, 150, 200 and $250 \mu \mathrm{g} / \mathrm{ml}$ ). Indeed, the released contents were found to be maximum at 60 mins and 120 mins of treatment with AFCs which reflects that AFCs in Aspergillus giganteus has potential effect on the pathogen and causes damage to the cell membrane thus, releasing the protein contents within a short period.

Leakage of glucose in the treated sample was found to be increased with exposure to increased concentration of AFCs with increased time. Release of increased glucose contents was observed at $\mathrm{OD}_{530}$ with exposure of AFCs to Aspergillus fumigatus at 120 mins of treatment. The amount of glucose leaked by the AFCs (50, 100, 150, 200 and $250 \mu \mathrm{g} / \mathrm{ml}$ ) at $120 \mathrm{mins}$ treated sample was $30.6 \pm 0.01 \mu \mathrm{g} / \mathrm{ml}, 47.6 \pm 0.01 \mu \mathrm{g} / \mathrm{ml}$, $53.8 \pm 0.01 \mu \mathrm{g} / \mathrm{ml}, 82.68 \pm 0.01 \mu \mathrm{g} / \mathrm{ml}$ and $109.8 \pm 0.01 \mu \mathrm{g} / \mathrm{ml}$. The leakage of components (DNA, RNA, protein and glucose) were released into the medium at a higher level in the treated pathogen than that of control (without AFCs treatment). 


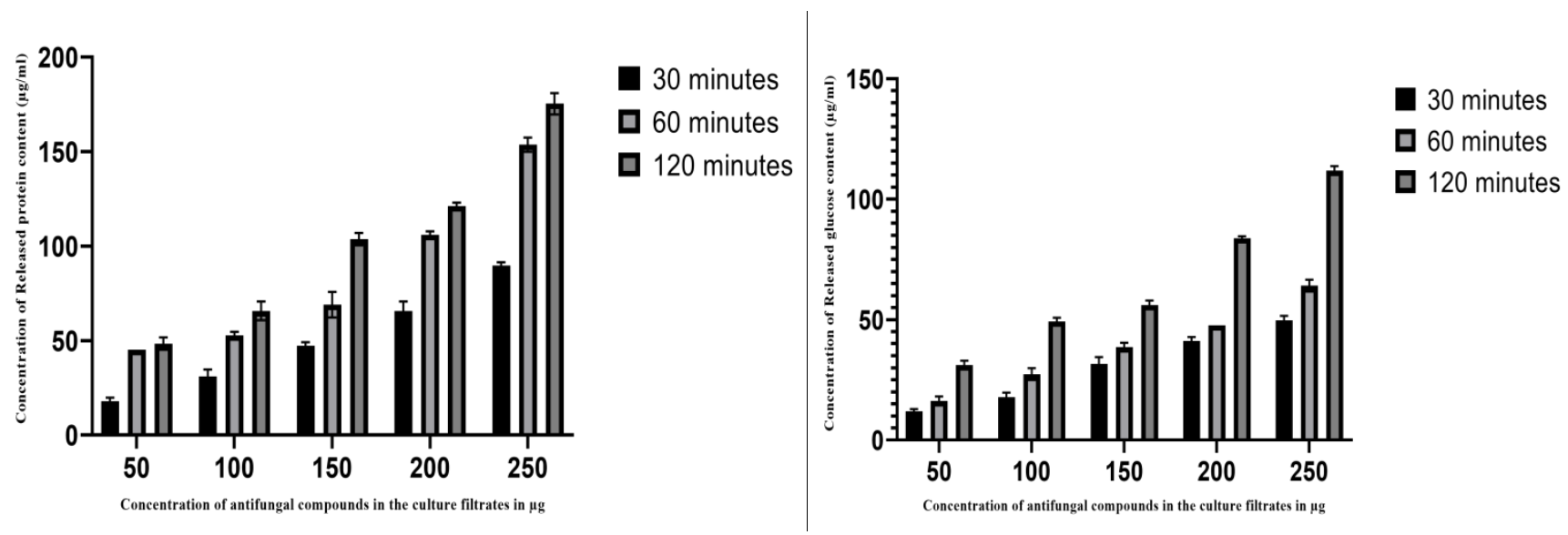

Fig. 3. Leakage of proteins (left side) and glucose (right side) from cell membrane of Aspergillus fumigatus treated with various concentrations of AFCs. The results are expressed as $\mu \mathrm{g} / \mathrm{ml}$ of proteins released. Data are represented as mean $\pm S D(n=3)$

\subsubsection{Release of lipids during membrane distortion}

The lipid content in the treated pathogenic cell membrane was measured by the absorbance at $520 \mathrm{~nm}$. Results of decreased lipid contents in AFCs treated Aspergillus fumigatus are represented in figure 4 . As depicted in the graph, the AFCs in the culture filtrate of $A$. giganteus have an inverse proportion of the lipid contents in the $A$. fumigatus cell membrane. The amount of lipid contents for the increased concentration of AFCs in Aspergillus giganteus was analyzed using phosphovanillin method. The lipid contents in Aspergillus fumigatus cell membrane were found to be $0.5 \pm 0.03 \mathrm{mg} / \mathrm{ml}$ and $0.2 \pm 0.02 \mathrm{mg} / \mathrm{ml}$ for $200 \mu \mathrm{g} / \mathrm{ml}$ and $250 \mu \mathrm{g} / \mathrm{ml}$ of AFCs, respectively.

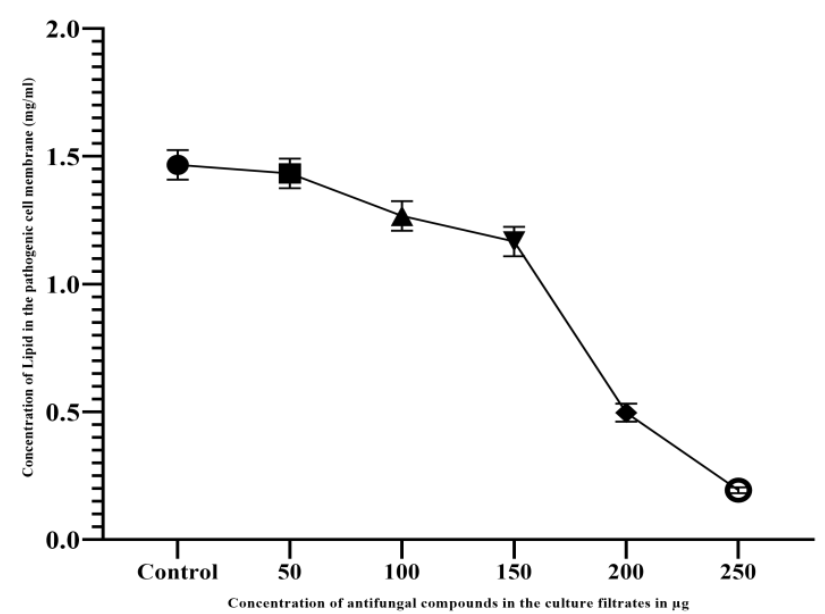

Figure 4. Evaluation of lipid contents in the Aspergillus fumigatus cell membrane treated with different concentrations of AFCs. Data are expressed as mean $\pm \mathrm{SD}(\mathrm{n}=3)$

\subsubsection{Cell wall protection assay}

\subsubsection{Sorbitol assay}

For elucidating the action of AFCs in Aspergillus giganteus, the sorbitol assay was performed on the pathogenic fungal cell wall with and without sorbitol in the medium. Since, sorbitol is acting as a cell wall protectant, the pathogenic strain was observed to be intact in the medium inoculated with $0.8 \mathrm{M}$ sorbitol even in the presence 
of AFCs at different concentrations (Table 1). Thus the AFCs could not damage the cell wall in the presence of sorbitol indicating its mode of action.

Table 1. Effect of AFCs in cell free supernatant of Aspergillus giganteus on the cell wall of Aspergillus fumigatus in the presence and absence of sorbitol

\begin{tabular}{llll}
\hline S.No & $\begin{array}{c}\text { Concentration of AFCs } \\
(\mu \mathrm{g} / \mathrm{ml})\end{array}$ & Medium with 0.8 M sorbitol & $\begin{array}{c}\text { Medium without 0.8 M } \\
\text { sorbitol }\end{array}$ \\
\hline 1. & Control (Without AFCs) & - & - \\
2. & 50 & - & - \\
3. & 100 & - & - \\
4. & 150 & - & + \\
5. & 200 & - & + \\
6. & 250 & - & + \\
\hline
\end{tabular}

(+) Inhibition (-) No inhibition

\subsubsection{Extracellular $\mathrm{pH}$ in treated Aspergillus fumigatus}

Examination of $\mathrm{pH}$ changes observed in the AFCs treated pathogenic strain was conducted using a $\mathrm{pH}$ meter. Results of $\mathrm{pH}$ variation are represented in Figure 5, where $\mathrm{pH}$ was shown to decrease gradually with time exposure and AFCs concentration. The $\mathrm{pH}$ level began to fall after 30 minutes of treatment compared to that of control (without AFCs). The decreased pH level in the treated pathogenic cell has revealed that might be some acids or any other acidic metabolites in the pathogenic strain may be leaked into the medium, thus changes in the $\mathrm{pH}$ were observed.

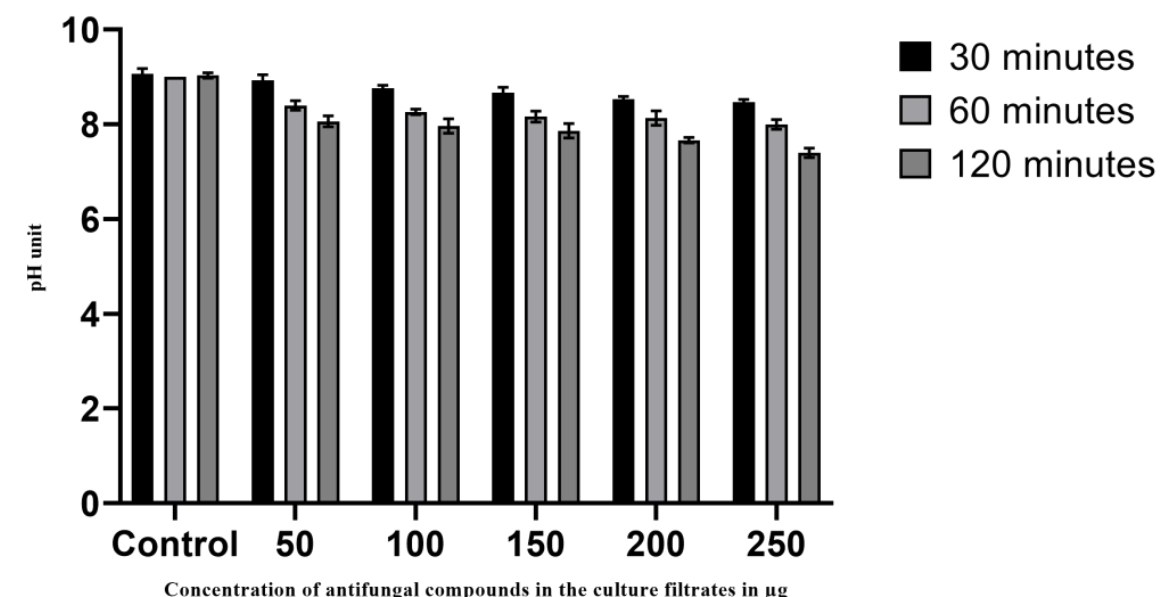

Figure 5:Determination of $\mathrm{pH}$ changes observed with different concentrations of AFCs on Aspergillus fumigatus. The notable changes in the $\mathrm{pH}$ were observed. Data are expressed as mean $\pm \mathrm{SD}(\mathrm{n}=3)$

\subsection{GC-MS profile of the bioactive metabolites}

The ethyl acetate extract of the culture filtrates of $A$. giganteus were subjected to GC-MS analysis and the run resulted in a GCMS chromatogram with their relative abundance. About 30 compounds in the spectrum obtained (Figure 6) were identified as fatty acids, methylated esters of fatty acids, flavones and sterol intermediates from 
polyketide synthase pathway. Among these compounds, the peaks of relatively abundant compounds were analysed and the compounds are listed in Table 2. The list of fatty acids and methyl esters identified are also given as supplementary figure S1. Several fatty acid metabolites, have been identified as antifungal compounds which are biodegradable with high specificity for many pathogenic fungi. It has also been found that pathogenic fungi do not become resistant with constant exposure to these antifungal fatty acids. These fatty acids incorporate themselves into the cell membranes of target pathogens and increase membrane fluidity and disruptions in the arrangement of membrane proteins which eventually releases the cellular constituents.

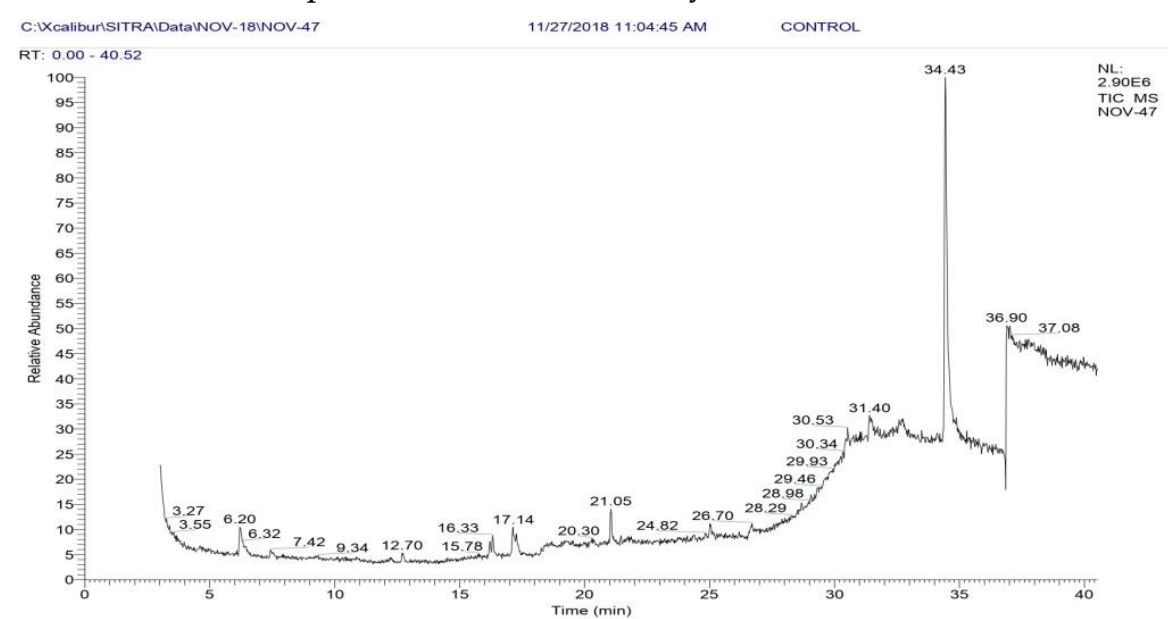

Figure 6. GC-MS chromatogram of culture filtrates of Aspergillus giganteus

Table 2. Bioactive compounds identified in the GC-MS spectrum of Aspergillus giganteus

\begin{tabular}{llll}
\hline S.No & $\begin{array}{l}\text { Retention } \\
\text { Time }\end{array}$ & Compound Name & $\begin{array}{l}\text { Approximate Relative } \\
\text { Abundance (\%) }\end{array}$ \\
\hline 1 & 15.53 & 6- hydroxyl-4- (methylthio) indane & $10-12$ \\
2 & 21.05 & 1,2,4- Trioxolane-2- octanoic acid, 5- octyl- methyl ester & 15 \\
3 & 24.82 & Cyclopropane butanoic acid & 13.5 \\
4 & 30.49 & Lucenin 2 & 27 \\
5 & 31.41 & $5,7,9$ (11)- Androstatriene, 3- hydroxyl-17- oxo & 35 \\
6 & 34.46 & 13- Docosenamide, $(Z)$ & 100 \\
7 & 38.13 & Fenretinide & 33.5 \\
\hline
\end{tabular}

\subsection{Cytotoxicity of antifungal compounds}

The hemolytic activity of antifungal compounds in cell free supernatant of Aspergillus giganteus was measured and used for the determination of its toxicity level. The result of cytotoxicity of AFCs in antagonistic fungus is given in Figure 7. The increased hemolysis was observed with an increased concentration of AFCs. $250 \mu \mathrm{g} / \mathrm{ml}$ of AFCs have shown $25 \pm 0.18$ percentage of hemolysis, thus it represents the least toxic level to the RBCs. From the results, it was clear that cell free supernatant of Aspergillus giganteus is found to be safe. 


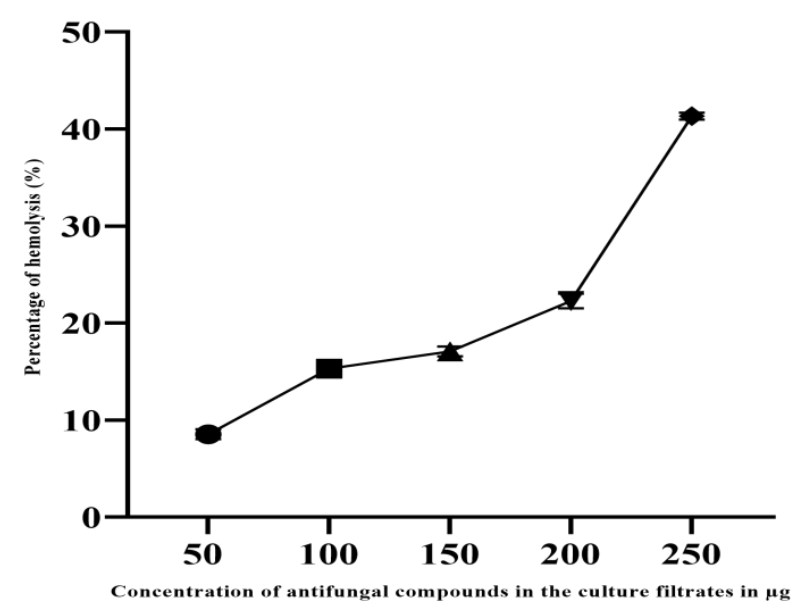

Figure 7. Percentage hemolysis of erythrocytes induced by the exposure of various concentrations of AFCs of Aspergillus giganteus. Results are expressed in mean $\pm \mathrm{SD}(\mathrm{n}=3)$

\subsection{ADMET profile of sarcin, thionin, chitinase and its derivatives of A. giganteus}

Supplementary Table S2 explains the profile of the selected compounds such as molecular weight, $\log \mathrm{P}$ value, rotatable bonds, acceptors, donars, and surface area. The ADME property of the fluconazole, sarcin, thionin, chitinase and its derivatives is listed in Table 3. The all the selected compounds were found to have a good absorption level except the chitinase derivative. The highest absorption was found with the sarcin and thionin derivatives. The intestinal absorption and skin permeability profile represent the selected compounds that have a good absorption profile compared with the standard drug, fluconazole. Sarcin from Aspergillus giganteus possesses to be distributed into the blood-brain barrier and central nervous system. The compounds were observed as neither substrate nor inhibitor for the cytochrome P450, which is an important detoxification enzyme found in the liver. The studies have given the way to conclude that the sarcin and its derivatives of the Aspergillus giganteus shown a good ADME profile while comparing with the standard antifungal drug. The toxicological properties of the sarcin, thionin, chitinase and its derivatives showing fewer toxic properties and it is contemplating that the selected compounds are safe for use to treat the fungal infection (Table 4).

\subsection{Molecular interaction of bioactive compounds with the virulence proteins}

Molecular simulation studies were performed to identify the best interaction of ligand molecules with the pathogenic target proteins which leads to the development of a wide range of drugs after undergone several layers of screening. The best selected three ligand molecules with the selected target proteins were docked at its active site. The missing hydrogen atoms were incorporated and proper ionization states were generated using the OPLS-2005 force field. For optimal molecular interactions, the 
minimization was done at last until the heavy atoms are converged to an RMSD of $0.30 \AA$. A grid box was generated around the 1 co-crystallized ligand in the receptor protein that allows the molecular docking into the active site of the protein. The cubic boxes 2 with the coordinates in the receptor grid generation correspond to the 3.336, 15.597 and 4.868 in $\mathrm{x}, \mathrm{y}$ and $\mathrm{z}$ directions respectively, 3 centered on the centroid of the co-crystallized ligand has been created. The weak force, Van der Waals radius scaling factor was set 4 to $1.0 \AA$ and the partial charge of cut off was maintained at 0.25 with no constraints. The sarcin, thionin, chitinase from Aspergillus 5 giganteus and fluconazole was docked with the virulence proteins of pathogenic Aspergillus fumigatus. Table 6 shows the molecular 6 interactions of sarcin, thionin, chitinase \& fluconazole with the pathogenic target proteins. The docking image with the virulence 7 proteins is depicted in Figure 8.

Table 3. ADME properties of sarcin, thionin, chitinase and its derivatives of Aspergillus giganteus

\begin{tabular}{|c|c|c|c|c|c|c|c|c|c|c|c|c|}
\hline \multirow{2}{*}{$\begin{array}{l}\text { PubChem } \\
\text { ID }\end{array}$} & \multicolumn{4}{|l|}{ Absorption } & \multicolumn{2}{|l|}{ Distribution } & \multicolumn{4}{|c|}{ Metabolism } & \multicolumn{2}{|l|}{ Excretion } \\
\hline & $\begin{array}{l}\text { Water } \\
\text { solubility } \\
(\log \mathrm{mol} / \mathrm{L})\end{array}$ & $\begin{array}{l}\text { Intestinal } \\
\text { Absorption } \\
\begin{array}{l}\text { (human) } \\
\text { absorbed) }\end{array}\end{array}$ & $\begin{array}{l}\text { Skin } \\
\text { Permeability } \\
(\operatorname{logKp})\end{array}$ & $\begin{array}{l}\text { Oral } \\
\text { absorption }\end{array}$ & $\begin{array}{l}\text { BBB } \\
\text { permeability } \\
(\log B B)\end{array}$ & $\begin{array}{l}\text { CNS } \\
\text { Permeability } \\
(\log \text { PS) }\end{array}$ & $\begin{array}{l}\text { CYP2D6 } \\
\text { substrate }\end{array}$ & $\begin{array}{l}\text { CYP3A4 } \\
\text { Substrate }\end{array}$ & $\begin{array}{l}\text { CYP2D6 } \\
\text { Inhibitor }\end{array}$ & $\begin{array}{l}\text { CYP3A4 } \\
\text { Inhibitor }\end{array}$ & $\begin{array}{l}\text { Total } \\
\text { Clearance } \\
\text { (log } \\
\mathrm{ml} / \mathrm{min} / \mathrm{k} \\
\mathrm{g}\end{array}$ & $\begin{array}{l}\text { Renal } \\
\text { OCT2 } \\
\text { Substra } \\
\text { te }\end{array}$ \\
\hline 3365 & -3.293 & 94.964 & -2.8 & High & -1.067 & -3.185 & No & No & No & No & 0.29 & No \\
\hline 3032391 & -3.027 & 100 & -2.735 & High & -1.105 & -3.779 & No & No & No & No & 0.609 & No \\
\hline 65044 & -3.487 & 91.621 & -3.31 & High & -0.158 & -1.952 & No & No & No & No & 0.153 & Yes \\
\hline 462371 & -2.071 & 74.632 & -3.157 & High & -0.157 & -0.157 & No & No & Yes & No & 1.175 & Yes \\
\hline 122678533 & -2.486 & 93.484 & -2.741 & Low & 0.17 & -2.812 & No & No & No & Yes & 0.075 & No \\
\hline 88094842 & -5.708 & 93.533 & -1.499 & High & 0.703 & -2.125 & No & Yes & No & No & 0.14 & No \\
\hline 86223064 & -3.391 & 95.19 & -2.765 & High & -0.457 & -2.659 & No & Yes & No & Yes & 0.914 & Yes \\
\hline 86223063 & -3.208 & 94.181 & -2.766 & High & -0.274 & -2.554 & No & Yes & No & No & 1.04 & Yes \\
\hline 6857375 & -1.38 & 31.963 & -3.234 & Medium & -0.618 & -3.694 & No & No & No & No & 0.711 & No \\
\hline & & & & & & & & & & & & $\begin{array}{l}10 \\
11 \\
12\end{array}$ \\
\hline
\end{tabular}


Table 4. Toxicological profile of sarcin, thionin, chitinase and its derivatives of Aspergillus giganteus

\begin{tabular}{|c|c|c|c|c|c|c|c|c|c|c|}
\hline \multirow[t]{2}{*}{ Ligand } & \multirow[t]{2}{*}{$\begin{array}{l}\text { AMES } \\
\text { Toxicity }\end{array}$} & \multirow{2}{*}{$\begin{array}{l}\text { Max. Tolerated } \\
\text { dose (human) } \\
\text { (log } \\
\mathrm{mg} / \mathrm{kg} / \text { day) }\end{array}$} & \multicolumn{2}{|c|}{$\begin{array}{l}\text { HERG } \\
\text { Inhibitor }\end{array}$} & \multirow{2}{*}{$\begin{array}{l}\text { Oral Acute } \\
\text { toxicity } \\
(\text { LD50)(mol/kg) }\end{array}$} & \multirow{2}{*}{$\begin{array}{lr}\text { Oral rat } & \text { chronic } \\
\text { toxicity } & \text { (LOAEL) } \\
\text { (Log } & \mathrm{mg} / \mathrm{kg} \\
\text { bw/day) } & \end{array}$} & \multirow[t]{2}{*}{ Hepatotoxicity } & \multirow[t]{2}{*}{$\begin{array}{l}\text { Skin } \\
\text { Senitization }\end{array}$} & \multirow[t]{2}{*}{$\begin{array}{l}\text { T.pyriformis } \\
\text { toxicity }(\log \mu \mathrm{g} / \mathrm{L})\end{array}$} & \multirow[t]{2}{*}{$\begin{array}{l}\text { Minnow toxicity } \\
(\log \mathrm{mM})\end{array}$} \\
\hline & & & I & II & & & & & & \\
\hline 3365 & No & 0.114 & No & No & 2.328 & 1.033 & Yes & No & 0.312 & 3.872 \\
\hline 3032391 & Yes & 0.649 & No & No & 2.454 & 0.855 & Yes & No & 0.285 & 2.272 \\
\hline 65044 & Yes & -0.3 & No & No & 2.532 & 1.885 & No & No & 1.041 & 0.686 \\
\hline 462371 & Yes & -0.188 & No & No & 2.478 & 1.661 & No & No & 0.495 & 1.142 \\
\hline 122675833 & Yes & 0.942 & No & Yes & 2.771 & 0.207 & Yes & No & 0.285 & 0.502 \\
\hline 88094842 & No & 0.18 & No & No & 2.137 & 0.794 & No & Yes & 3.193 & 0.494 \\
\hline 86223064 & No & -0.21 & No & Yes & 2.588 & 0.663 & Yes & No & 0.297 & -1.049 \\
\hline 6857375 & No & 1.944 & No & No & 1.547 & 3.406 & No & No & 0.285 & 4.705 \\
\hline
\end{tabular}




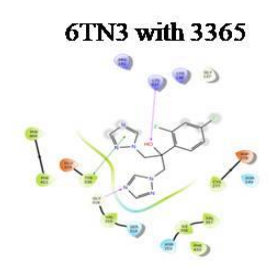

4CAW with 3365
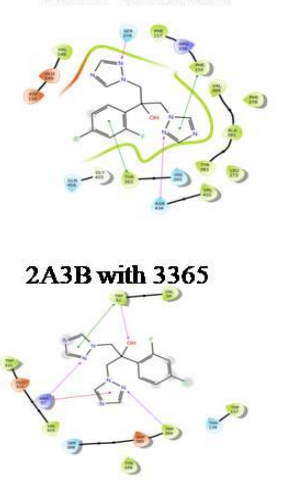

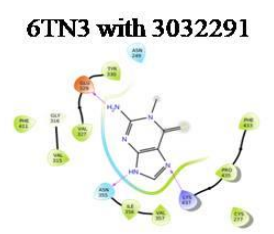

4CAW with 3032291

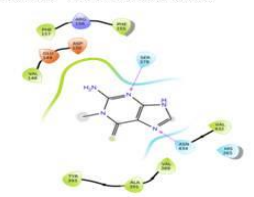

2A3B with 3032291
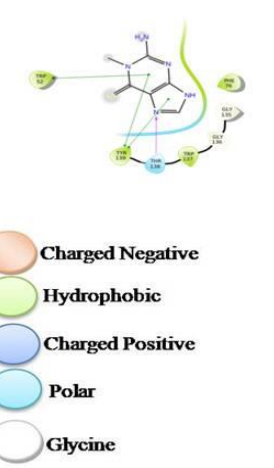

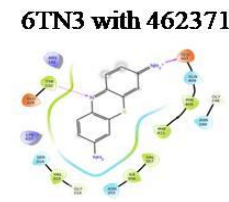

4CAW with 462371

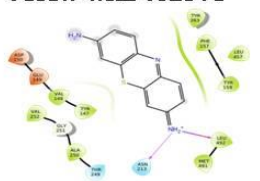

2A3B with 462371
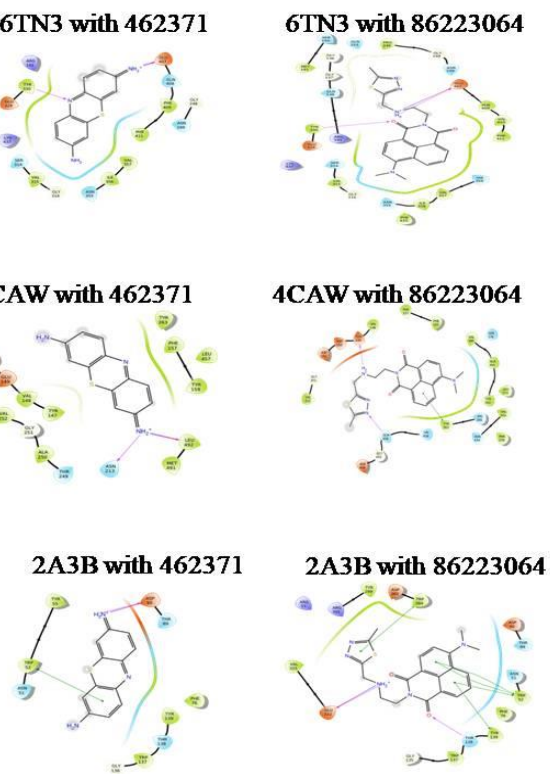

Figure 8. Molecular interactions of Fluconazole (3365) and Sarcin (3032391 \& 65044) from A. giganteus with the various pathogenic target proteins of $A$. fumigatus

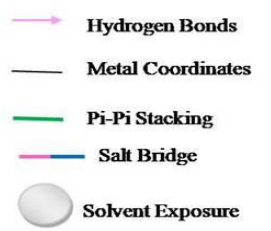

15

\section{Discussion}

The treatment and discovery of suitable drugs for fungal infections still pose formidable challenges in the world [37,2]. The application of antimicrobial compounds from natural sources acts as good platform for the drug development $[38,41,46]$. The screening of effective antibiotics from natural sources had been highlighted in the past. Nowadays the ratio of discovering new and valuable antibiotics falls annually, hence there is a need for the production of novel antibiotics for the treatment of infections. Researchers and scientists have focused to discover antimicrobial compounds from antagonistic microorganisms [42-44].

Aspergillus giganteus is a potential antagonistic fungus. Several studies claimed that the antifungal compounds in Aspergillus giganteus are protein in nature [23-26]. Aspergillus fumigatus a well known aspergillosis causing organism was targeted by the antagonistic fungus to inhibit its pathogenesis. Indeed, the exact underlying mode of action of Aspergillus giganteus remains elusive. Nevertheless, it is popular for producing a kind of antifungal compound, AFP (Anti-Fungal Proteins) [12]. The mechanism of Aspergillus giganteus AFCs against Aspergillus fumigatus was explained in this study.

The antifungal compounds from antagonistic fungus were reported by many authors, including its function [39,40,45,17]. The damage caused by the AFCs of Aspergillus giganteus was determined by SEM analysis. The bioactive metabolites 
responsible for the antagonistic nature of Aspergillus giganteus was identified by GC-MS profiling. In our study, the mechanistic action of AFCs of Aspergillus giganteus was determined by assessing the integrity of the cell membrane and cell wall of the pathogenic strain, Aspergillus fumigatus. Many studies have supported the techniques used to determine the mode of action of antagonistic compounds [26,31]. Indeed, the AFCs are extracellular and protein in nature, the cell free supernatant of Aspergillus giganteus was prepared to study its mechanisms. Different concentrations of AFCs in culture filtrates such as 50,100,150, 200 and $250 \mu \mathrm{g} / \mathrm{ml}$ was selected for testing its potential on the pathogenic cell membrane and cell wall.

AFCs caused damage to the structure of pathogenic strain, Aspergillus fumigatus and it was confirmed by SEM analysis. The structural distortion of treated pathogenic strain has proved the antagonistic nature of AFCs of Aspergillus giganteus. Several research studies have correlated with the results of present study is discussed $[33,34]$.

The fungal cell wall and cell membrane are essential for maintaining the structure and function of fungi $[35,43,44]$. The action of AFCs from Aspergillus giganteus was proved using absorbing the released cellular contents through pathogenic cell membrane into the medium. The release of cell constituents in the treated pathogenic strain was measured using absorbance $260 \mathrm{~nm}$ for nucleic acids, $670 \mathrm{~nm}$ for proteins and $630 \mathrm{~nm}$ for glucose. In this context, the cellular constituents were released into the medium in a time and concentration dependent manner. The cell membrane provides a barrier for transporting extra and intra cellular constituents [28,50]. The proteins and glucose are the important cell membrane components needed for the maintenance of cell membrane integrity and function. Cytoplasmic constituents such as DNA, RNA, protein and glucose that are released from the cell membrane of pathogenic strain to the medium is considered as the indicator for the disturbance and damage occurred in the membrane integrity by the AFCs used. The activity of AFCs on pathogenic fungal cell membrane, clearly stated that the released constituents such as DNA \& RNA were released gradually into the medium with the increased time of exposure and concentration of AFCs.

Lipid is the important component in the cell membrane responsible for maintaining the permeability, fluidity and function of integral membrane proteins. Several antifungal compounds have already been reported that the main target for affecting the pathogenic fungi is lipids and mechanism behind is either inhibiting the lipid biosynthesis or binding to it, thus causing formation of pores in the cell membrane [32]. The present study represented that the AFCs of Aspergillus giganteus has effectively exhibited their potential on the lipids in the cell membrane of Aspergillus fumigatus. The increased exposure of AFCs has a great effect on the cell membrane, thus reducing the lipid contents in the pathogenic cellular membrane. Several scientific studies have mentioned the mechanisms used to study the cell membrane integrity and have proved the damage of cellular membrane occurred with treated antimicrobial substances leading to the release of macromolecules [47-50].

Fungal cell walls are dynamic and very complex structures, and they are responsible for maintaining the shape and the integrity of the fungal cell [51]. Sorbitol is 
an osmotic protectant that protects the fungal cell wall used to stabilize protecting the fungi from environmental stress especially during osmotic changes. Our results are encouraging that the medium without sorbitol showed the inhibition with different concentrations of AFCs. Medium with sorbitol acts as a cell wall protectant, therefore, the pathogenic cells remain undamaged in the presence of AFCs. Similar results were observed with various studies [31,52]. Therefore, the sorbitol assay reiterated that the AFCs act on the cell wall of pathogenic Aspergillus fumigatus.

The transport of ions and their permeability via cell membrane is managed by the structure and composition of cell wall and cell membrane. Any disturbance in the ion homeostasis ultimately affects the cell metabolism and leads to the death of pathogenic strains [53]. Generally, AFCs affects the lipids in the pathogenic cell membrane, thus disturbing the structure of cell membrane and it might become more permeable causing release of some ions and acidic metabolites into the medium where changes in the extracellular $\mathrm{pH}$ were noted. Moreover, our results also explained that the extracellular $\mathrm{pH}$ of the treated Aspergillus fumigatus was observed with increased exposure of time and AFCs concentrations.

The GC-MS profiling of the metabolites have been proved to possess antifungal properties that were abundantly present and the antifungal nature of the culture filtrates may be attributed to this. Various scientific pieces literatures have also been correlated with the results obtained in our study [54,55].

Hemolytic activity is used to measure the therapeutic index of antimicrobial substances [36-38]. The hemolysis of red blood cells is an alternative screening method to determine the toxicity of antimicrobials. This method is an effective, reproducible and cheapest method to evaluate the toxicity of antimicrobial compounds, minimizing the animal sacrifice. Hemolysis occurred when the membrane lipid bilayer gets damaged, thus destroying red blood cells [37,56]. In our study the hemolysis assay (fig. 9) showed that it is completely concentration dependent. These results are in concordance with other research where the hemolysis was increased with increased concentration of antimicrobials [57-59].

The in silico approaches have provided a way to understand the nature and characteristics of the molecules in the candidate to develop a novel drug by pharmaceutical industries. Based on the literature studies the sarcin, thionin, chitinase and its derivatives from the Aspergillus giganteus and their structures were downloaded from the PubChem databases. Their ADMET (Absorption, Distribution, Metabolism, Excretion and Toxicity) profile was predicted by the online software. The pathogenic target proteins responsible or the virulence nature is downloaded from the PDB databases. The molecular interaction studies have proved the active binding of ligand molecules with the target proteins of Aspergius fumigatus, thus, it can be used to prevent and management of aspergillosis. The present study confirmed that the antifungal compounds from Aspergillus giganteus is safe and can be an effective lead compound for pharmaceutical industry to control the aspergillosis infections in human. 


\section{Materials and Methods}

\subsection{Fungal strains and culture conditions}

Aspergillus fumigatus a pathogenic strain (PSGIMS, Coimbatore) was selected to investigate the mode of action of Aspergillus giganteus (8408) which was procured from Microbial Type Culture Collection, Institute of Microbial Technology (IMTECH), Chandigarh. The fungal strains were maintained on czapek yeast extract medium (CYE) at $4^{\circ} \mathrm{C}$ for storage. Before applications, the fungal strains were revived and subcultured on the same medium at $28 \pm 2^{\circ} \mathrm{C}$ in dark conditions for $4-7$ days. Our pilot studies have proved that the active metabolites in the Aspergillus giganteus is secreted extracellularly [19]. In this regard, the cell-free supernatant was chosen to assess its potential mechanism on the pathogenic cell wall.

\subsection{Preparation of cell-free supernatant}

The cell free supernatant from Aspergillus giganteus was prepared by the stepwise procedure. Briefly, the fungal strain was grown on the optimized culture medium (CYE) at $28 \pm 2^{\circ} \mathrm{C}$ for 4-7 days. After incubation, the culture was filtered through 8 layered cheesecloth to remove the mycelia. The collected supernatant was filtered through a $0.22 \mu \mathrm{m}$ membrane filter to obtain cell-free culture filtrates which were stored at $4^{\circ} \mathrm{C}$ before use. The amount of protein in the cell-free supernatant was determined by Lowry's method [27].

\subsection{Scanning Electron Microscopic Analysis}

The cell morphology of the Aspergillus fumigatus was analysed by scanning electron microscopy after being treated with the culture filtrates of Aspergillus giganteus. The 4 day old culture of Aspergillus fumigatus was treated with the AFCs of Aspergillus giganteus and the inhibition zone was subjected to $4.0 \%$ glutaraldehyde in $0.05 \mathrm{~mol} / \mathrm{l}$ phosphate-buffered saline at $4^{\circ} \mathrm{C}$ for fixation. The fixation was carried out for 4 to 6 hours and then the samples were washed with distilled water three times for 20 minutes each. Sequential dehydration with ethanol dilutions (30\%, 50\%, 70\% and 90\% ethanol in distilled water) was performed for 20 minutes and finally with absolute ethanol for 45 minutes. Following drying, the samples prepared were mounted on standard $1 / 2$ in SEM stubs using double-stick adhesive tabs and coated with gold-palladium, and analysed by FE-SEM (Zeiss) instrument by applying $5 \mathrm{kV}$ to view under different resolutions.

\subsection{Antifungal disruption mechanisms}

4.4.1. Preparation of mycelial suspension of the pathogenic strain

Inoculum of $5 \mathrm{~mm}$ sized mycelial mat with spores of Aspergillus fumigatus from the freshly grown plate was introduced into the $100 \mathrm{ml}$ of czapek yeast extract broth. It was kept at $28 \pm 2^{\circ} \mathrm{C}$ for $4-7$ days in the dark. After incubation, the culture broth was centrifuged at $4000 \mathrm{~g}$ for 20 minutes to collect the mycelia. The pellet was washed thrice with phosphate buffered saline ( $\mathrm{pH} 7.0)$. It was resuspended in $100 \mathrm{ml}$ phosphate buffered saline for the following studies. 
4.4.2. Cell membrane integrity on Aspergillus fumigatus

4.4.2.1. Cellular leakage of nuclear components via cell membrane

The integrity of the cell membrane of pathogenic strain could be determined by the release of cytoplasmic constituents (DNA \& RNA) and cell wall constituents (Protein and Glucose) [28,29]. The treatment begins with the suspensions of the pathogen were treated with AFCs at various concentrations $(50-250 \mu \mathrm{g} / \mathrm{ml})$ and incubated at $28 \pm 2^{\circ} \mathrm{C}$ under agitation in an environmental incubator shaker for $0,30,60$ and 120 minutes. Subsequently, $2 \mathrm{ml}$ of the sample was collected and centrifuged at $12000 \mathrm{~g}$ for 2 minutes. The supernatant was taken to determine the amount of cytoplasmic constituents such as DNA \& RNA by measuring the absorbance at $260 \mathrm{~nm}$.

\subsubsection{Release of protein and glucose through the cell membrane}

The cell membrane integrity of pathogenic strain was evaluated by calculating the release of protein and glucose into the medium. The concentrations of proteins and glucose released from the cell membrane were estimated using Lowry's method and Anthrone method $[27,30]$. The treatment was given as same as in the above method $(50-250 \mu \mathrm{g} / \mathrm{ml}$ of AFCs and time intervals of 0, 30, 60 and $120 \mathrm{mins}) .2 \mathrm{ml}$ of the treated sample was taken in appropriate time intervals (12000 $\mathrm{g}$ for $2 \operatorname{mins}$ at $\left.4^{\circ} \mathrm{C}\right)$ and read at $670 \mathrm{~nm}$ for proteins and $630 \mathrm{~nm}$ for glucose.

\subsubsection{Evaluation of lipid content in the AFCs treated pathogenic cell membrane}

Lipids are the major component of the cell membrane to maintain the structure and its integrity [31,32]. The lipid concentrations in the treated pathogenic cell membrane were determined by phosphovanillin method. The 2 day old mycelia from $50 \mathrm{ml} \mathrm{CYE}$ broth were collected by centrifuging it at $4000 \mathrm{~g}$ for 10 minutes. The pellet was dried with a vacuum freeze drier for 4 hours. $0.1 \mathrm{~g}$ of dry mycelia was homogenized with liquid nitrogen followed by the extraction with $4 \mathrm{ml}$ of methanol:chloroform:water mixture $(2: 1: 0.8, \mathrm{v} / \mathrm{v} / \mathrm{v})$ in a clean dry test tube with vigorous shaking for 30 minutes. The tubes were centrifuged at $4000 \mathrm{~g}$ for 10 minutes. An aliquot of $0.2 \mathrm{ml}$ chloroform and liquid mixture was transferred to another clean dry test tube. To which $0.5 \mathrm{ml} \mathrm{H}_{2} \mathrm{SO}_{4}$ was added and heated for 10 minutes in a boiling water bath. After that, $3 \mathrm{ml}$ of phosphovanillin reagent was added (vigorous shaking) and kept for incubation at room temperature for 10 minutes. The amount of lipid content in the pathogenic cell membrane was calculated by measuring the absorbance at $520 \mathrm{~nm}$. Cholesterol can be used as a standard.

\subsubsection{Cell wall protection mechanisms}

\subsubsection{Sorbitol assay}

The effect of the AFCs on the pathogenic cell wall could be determined by with and without the addition of sorbitol in the medium. Sorbitol act as a fungal cell wall osmotic protective agent, when this sorbitol is added to the culture medium it protects the cell wall of fungi [33]. This sorbitol assay implicated the cell wall as one of the possible cell targets for the product tested thereby used to evaluate the possible 
mechanisms of AFCs on the pathogenic cell wall. The sorbitol was added to the culture medium to give a final concentration of $0.8 \mathrm{M}$. Then the plate was incubated at $25^{\circ} \mathrm{C}$. The plates were read after 48 hours and 7 days at $595 \mathrm{~nm}$.

In order to check the cell wall permeability, the $\mathrm{pH}$ of the medium could be monitored by $\mathrm{pH}$ meter. The experiment started with the inoculation of pathogenic fungal suspensions into the CYE medium and kept for incubation in a moist chamber at $28 \pm 2^{\circ} \mathrm{C}$ for 2 days. Then it was centrifuged at $4000 \mathrm{~g}$ for 20 minutes and the pellet was washed for 2-3 times with sterile double distilled water. Then different concentrations of AFCs $(50-250 \mu \mathrm{g} / \mathrm{ml})$ were added and the $\mathrm{pH}$ of the medium was check for every 0 , 30, 60 and 120 minutes to observe the changes in the $\mathrm{pH}$ in the treated sample.

4.5. Gas chromatography-Mass spectrometry (GC-MS) profiling of the bioactive metabolites of Aspergillus giganteus

The bioactive metabolite profile of Aspergillus giganteus was studied by procuring the culture filtrates from the A. giganteus and subjecting them to ethyl acetate extraction $(1: 1 \mathrm{v} / \mathrm{v})$. The collected extract was concentrated in a rotary evaporator and $1 \mu \mathrm{l}$ of this sample was subjected to GCMS analysis in Thermo GC-MS DSQ instrument. A standard non-polar column was used with helium as carrier gas (flow rate $1 \mathrm{ml} / \mathrm{min}$ ) and oven temperature set from 70 to $260^{\circ} \mathrm{C}$. The metabolites obtained in the spectra were compared to the reference spectra in the NIST- Wiley database.

\subsection{Cytotoxicity of AFCs in Aspergillus giganteus culture filtrates}

Cytotoxicity of the AFCs present in the culture filtrates of Aspergillus giganteus were determined using goat red blood cells. Briefly, $4 \%$ suspension of goat red blood cells (gRBCs) was treated with various concentrations of AFCs $(50-250 \mu \mathrm{g} / \mathrm{ml})$. The gRBCs were washed thrice with phosphate buffered saline. $100 \mu \mathrm{l}$ of aliquots of gRBCs suspension was added to 96 well microtitre plates followed by the addition of $100 \mu \mathrm{l}$ of each concentration of AFCs in PBS to the subsequent well. This mixture was kept at $37^{\circ} \mathrm{C}$ for 1 hour. Then, mixture was centrifuged at $1500 \mathrm{rpm}$ for 10 minutes, and aliquots were transferred to a new dry well. The absorbance was measured at $414 \mathrm{~nm}$ using an ELISA reader. Hemolytic rates of $0 \%$ and $100 \%$ were determined with PBS \& $0.1 \%$ Triton X-100, respectively. The hemolysis percentage was calculated using the equation: Percent hemolysis (\%) = [Abs 414nm in the compound solution-Abs 414nm in PBS] [ [Abs 414nm in $0.1 \%$ Triton X 100 -Abs $414 \mathrm{~nm}$ in PBS] X 100.

4.7. Bioavailability and toxicological properties of sarcin, thionin and chitinase and its derivatives of Aspergillus giganteus

The ADMET (Absorption, Distribution, Metabolism, Excretion and Toxicological properties) profile of compounds of Aspergllius giganteus including, sarcin, thionin and chitinase and its derivatives $[13,60]$ were studied by the software pkCSM (http://biosig.unimelb.edu.au/pkcsm/prediction\#). The standard drug fluconazole 
activity was also predicted to compare the efficiency of compounds of A. giganteus. Various parameters were predicted for the compounds.

240

\subsection{Molecular interaction studies}

The pathogenic protein targets were downloaded in 3 dimensional, pdb format in the PDB database (http://www.rcsb.org/pdb). The selected proteins namely, UDP-N-acetylglucosamine pyrophosphorylase (6TN3), N-myristoyl transferase (4CAW) and Chitinase (2A3B) are cell wall proteins that are essential for the virulence properties of Aspergillus fumigatus. Molecular docking studies of compounds with the target proteins were performed using Maestro v11.8 (Schrodinger Release 2018-4: Glide, Schrodinger, LLC, New York, NY, 2018). The downloaded protein structures were prepared by Protein Preparation Wizard module of Schrodinger software.

\subsection{Statistical Analysis}

All the experiments were carried out in triplicates and the values are expressed as mean \pm SD. The mechanistic studies were analyzed using Two-way ANOVA in order to determine the statistical significance. The difference is significant for $\mathrm{p}$-value $\leq 0.05$ of the performed experimental data.

\section{Conclusions}

The application of antimicrobial compounds from natural sources, especially microorganisms has become a great tool for the production and discovery of novel drugs for the treatment and prevention of fungal infections. The structural and morphological changes in the AFCs treated Aspergillus fumigatus have revealed that the potential application of AFCs of Aspergillus giganteus for the effective inhibition. Consecutively, the present work exploits the application of AFCs from Aspergillus giganteus on the cell wall and cell membrane of Aspergillus fumigatus, aspergillosis causing pathogen. This study emphasizes the mechanism of action of AFCs in the antagonistic fungi against the pathogenic cell. An irreversible gross morphological change in the treated pathogenic strain was noted, thus causing the release of cellular and cytoplasmic constituents. The GC-MS profiling of bioactive metabolites in the Aspergillus giganteus further explains the nature of bioactive metabolites. Moreover, the cytotoxicity level of AFCs of Aspergillus giganteus proved the safer level of AFCs. The interaction studies have given the pave to understand the sarcin is an effective ligand to inhibit the Aspergillus fumigatus to manage the infection, aspergillosis in human. This study strongly revealed the role of antifungal proteins of Aspergillus giganteus reiterating its antagonistic nature for treating the pathogen causing aspergillosis.

\section{Patents - Nil}

Supplementary Materials: Figure S1: Fatty acids and methyl esters identified in GC-MS of bioactive compounds of Aspergillus giganteus, Table S1: Profile description of sarcin, thionin, chitinase and its derivatives of Aspergillus giganteus

Author Contributions: “Conceptualization, K.D.; methodology, R.R., K.S.; software, J.N.S.; validation, K.D., R.R. and R.K.; formal analysis, R.R.; investigation, R.R.; resources, K.C.; data curation, 
R.K.; writing-original draft preparation, R.R.; writing-review and editing, R.R. K.D.; supervision, K.D., K.C.; project administration, K.D.; funding acquisition, K.C. All authors have read and agreed to the published version of the manuscript."

Funding/ Acknowledgments: The authors are thankful to King Khalid University (KKU), Saudi Arabia for providing financial support through the Small Research Program (Grant Approval Number: 275/1442).

Conflicts of Interest: "The authors declare no conflict of interest."

\section{References}

1. Vallieres, C.; Raulo, R.; Dickinson, M.; Avery, S.V. Novel combinations of agents targeting translation that synergistically inhibit fungal pathogens. Front. Microbiol. 2018, 9(2355), 1-15. https://doi.org/10.3389/fmicb.2018.02355

2. Bouyahya, A.; Bakri, Y.; Et-Touys, A.; Talbaoui, A.; Khouchlaa, A.; Charfi, S.; Abrini, J.; Dakka, N. Resistance to antibiotics and mechanisms of action of essential oils against bacteria. Phytotherapie 2017, 3, 1-11. https://doi.org/10.1007/s10298-017-1118-z

3. Saechow, S.; Thammasittirong, A.; Kittakoop, P.; Prachya, S.; Thammasittirong, S.N.R. Antagonistic activity against dirty panicle rice fungal pathogens and plant growth- promoting activity of Bacillus amyloliquefaciens BAS23. J. Microbiol. Biotechnol 2018 28(9), 1527-1535. https://doi.org/10.4014/jmb.1804.04025

4. Mircus, G.; Albert, N.; Ben-Yaakov, D.; Chikvashvili, D.; Shadkchan, Y.; Kontoyiannis, D.P.; Osherov, N. Identification and characterization of a novel family of selective antifungal compounds (CANBEFs) that interfere with fungal protein synthesis. Antimicrob. Agents Chemother 2015 59(9), 5631-5640. https://doi.org/10.1128/AAC.00850-15

5. Parente-Rocha, J.A.; Bailão, A.M.; Amaral, A.C.; Taborda, C.P.; Paccez, J.D.; Borges, C.L.; Pereira, M. Antifungal resistance, metabolic routes as drug targets, and new antifungal agents: an overview about endemic dimorphic fungi. Mediat. Inflamm. 2016, 1-16. https://doi.org/10.1155/2017/9870679

6. Scorzoni, L.; Benaducci, T.; Almeida, A.M.F.; Silva, D.H.S.; Bolzani, V.D.S.; Gianinni, M.J.S.M. The use of standard methodology for determination of antifungal activity of natural products against medical yeasts Candida sp and Cryptococcus sp. Braz. J. Microbiol. 2007 38, 391-7.

7. Glampedakis, E.; Coste, A.T.; Aruanno, M.; Bachmann, D.; Delarze, E.; Erard, V.; Lamoth, F. Efficacy of antifungal monotherapies and combinations against Aspergillus calidoustus. Antimicrob Agents Chemother 2018 62(12), 1137-18. https://doi.org/10.1128/AAC.01137-18

8. Reece, E.; Doyle, S.; Greally, P.; Renwick, J.; McClean, S. Aspergillus fumigatus inhibits Pseudomonas aeruginosa in co-culture: implications of a mutually antagonistic relationship on virulence and inflammation in the CF airway. Front. Microbiol. 2018 9(1205) 1-12. https://doi.org/10.3389/fmicb.2018.01205

9. Soltani, J. Secondary metabolite diversity of the genus Aspergillus: recent advances. In: New and Future Developments in Microbial Biotechnology and Bioengineering, Chapter 222016 275-92.

10. Garcia-Rubio, R.; de Oliveira, H.C.; Rivera, J.; Trevijano-Contador, N. The fungal cell wall: Candida, Cryptococcus, and Aspergillus species. Front. Microbiol 2020 10, 2993. https://doi.org/10.3389/fmicb.2019.02993

11. Lee, M.J.; Sheppard, D.C. Recent advances in the understanding of the Aspergillus fumigatus cell wall. J. Microbiol. 2016 54(3), 232-42. https://doi.org/10.1007/s12275-016-6045-4

12. Al-Maqtoofi, M.Y.; Burghal, A.A.; Al-Muosawi, A.A. Screening of Antibacterial Activity From Aspergillus Species Treated with Synthetic Antifungal Agent, Asian J Microbiol Biotechnol Environ Sci 2019 21(2), 335-338.

13. Moreno, A.B.; Martínez Del Pozo, A.; San Segundo, B. Antifungal mechanism of the Aspergillus giganteus AFP against the rice blast fungus Magnaporthe grisea. Appl. Microbiol. Biotechnol 2006 54, 245-59. https://doi.org/10.1007/s00253-006-0362-1

14. Meyer, V. A small protein that fights fungi: AFP as a new promising antifungal agent of biotechnological value. Appl. Microbiol. Biotechnol 2008 78(1), 17-28. https://doi.org/10.1007/s00253-007-1291-3

15. Hegedüs, N.; Marx, F. Antifungal proteins: more than antimicrobials?. Fungal Biol. Rev 2013 26(4), $132-145$. https://doi.org/10.1016/j.fbr.2012.07.002

16. Binder, U.; Bencina, M.; Eigentler, A.; Meyer, V.; Marx, F. The Aspergillus giganteus antifungal protein AFP NN5353 activates the cell wall integrity pathway and perturbs calcium homeostasis. BMC Microbiol 2011 11(1), 1-13.

17. Barakat, H.; Spielvogel, A.; Hassan, M.; El-Desouky, A.; El-Mansy, H.; Rath, F.; Meyer, V.; Stahl, U. The antifungal protein AFP from Aspergillus giganteus prevents secondary growth of different Fusarium species on barley. Appl. Microbiol. Biotechnol 2010 87(2), 617-24.https://doi.org/10.1007/s00253-010- 2508-4

18. Ghorbanpour, M.; Omidvari, M.; Abbaszadeh-Dahaji, P.; Omidvar, R; Kariman, K. Mechanisms underlying the protective effects of beneficial fungi against plant diseases. Biol. Control $2018 \quad 117, \quad 147-57$. https://doi.org/10.1016/j.biocontrol.2017.11.006

19. Krishnamurthy, R.; Padma, P.R.; Dhandapani, K. Antagonistic Efficiency of Aspergillus giganteus as a Biocontrol Agent against Aflatoxigenic Aspergillus flavus Infecting Maize.J. Pure Appl. Microbiol 2020 14(1), 527-39. https://doi.org/10.22207/JPAM.14.1.55 
20. Dutta, D.; Das, M.D. Optimization and partial characterization of intracellular anticandidal protein from Aspergillus giganteus MTCC 8408 using taguchi DOE. Bioengineered 2017 8(5), 536-48. https://doi.org/10.1080/21655979.2016.1264539

21. Hagen, S.; Marx, F.; Ram, A.F.; Meyer, V. The antifungal protein AFP from Aspergillus giganteus inhibits chitin synthesis in sensitive fungi. Appl. Environ. Microbiol 2007 73(7), 2128-34. https://doi.org/10.1128/AEM.02497-06

22. Moreno, A.B.; Del Pozo, A.M.; Borja, M.; Segundo, B.S. Activity of the antifungal protein from Aspergillus giganteus against Botrytis cinerea. Phytopathology 2003 93(11), 1344-53.

23. Boutheina, M.T.; Raina, A.B.A.; Nawaim, A.; Mejda, D.R. Antifungal potential of extracellular metabolites from Penicillium spp. and Aspergillus spp. naturally associated to potato against Fusarium species causing tuber dry rot, J. Microb. Biochem. Technol 2017 9(4), 181-190. https://doi.org/10.4172/1948-5948.1000364

24. Vila, L.; Lacadena, V.; Fontanet, P.; Del Pozo, A.M.; Segundo, B.S. A protein from the mold Aspergillus giganteus is a potent inhibitor of fungal plant pathogens. Mol Plant Microbe Interact 2001 14(11), 1327-31.

25. Tong, S.; Li, M.; Keyhani, N.O.; Liu, Y.; Yuan, M.; Lin, D.; Jin, D.; Li, X.; Pei, Y.; Fan, Y. Characterization of a fungal competition factor: production of a conidial cell-wall associated antifungal peptide. PLoS Pathog 2020 16(4), 1008518. https://doi.org/10.1371/journal.ppat.1008518

26. Theis, T.; Wedde, M.; Meyer, V.; Stahl, U. The antifungal protein from Aspergillus giganteus causes membrane permeabilization. Antimicrob Agents Chemother 2003 47(2), 588-93. https://doi.org/10.1128/AAC.47.2.588-593.2003

27. Lowry, O.H.; Rosebrough, N.J.; Farr, A.L.; Randall, R.J. Protein measurement with the Folin phenol reagent. J. Biol. Chem 1951 193, 265-75.

28. Bouyahya, A.; Abrini, J.; Dakka, N.; Bakri, Y. Essential oils of Origanum compactum increase membrane permeability, disturb cell membrane integrity, and suppress quorum-sensing phenotype in bacteria. J. Pharm. Anal 2019 9(5), 301-11. https://doi.org/10.1016/j.jpha.2019.03.001

29. Chen, C.Z.; Cooper, S.L. Interactions between dendrimer biocides and bacterial membranes. Biomaterials 2002 23(16), 3359-68.

30. Ludwig, T.G.; Goldberg, H.J. The anthrone method for the determination of carbohydrates in foods and in oral rinsing. J. Dent. Res 1956 35(1), 90-4. https://doi.org/10.1177/00220345560350012301

31. Lima, A.L.A.; Perez, A.L.A.L.; Sousa, J.P.; Pinheiro, L.S.; Oliveira-Filho, A.A.; Siqueira-Junir, J.P.; Lima, E.O. Antifungal Activity of Geraniol on Candida albicans Isolates of Pediatric Clinical Importance. Int. J. Pharmacogn. Phytochem. Res 2017 9(4), 581-6 https://doi.org/10.25258/phyto.v9i2.8131

32. Song, J.; Zhai, P.; Zhang, Y.; Zhang, C.; Sang, H.; Han, G.; Keller, N.P.; Lu, L. The Aspergillus fumigatus damage resistance protein family coordinately regulates ergosterol biosynthesis and azole susceptibility. MBio 2016 7(1), 01919-15. https://doi.org/10.1128/mBio.01919-15

33. Lipińska, L.; Klewicki, R.; Sójka, M.; Bonikowski, R.; Żyżelewicz, D.; Kołodziejczyk, K.; Klewicka, E. Antifungal activity of Lactobacillus pentosus ŁOCK 0979 in the Presence of Polyols and Galactosyl-Polyols. Probiotics Antimicrob. Proteins 2018 10(2), 186-200. https://doi.org/10.1007/s12602-017-9344-0

34. El-Kadi, S.M.; El-Fadaly, H.A.; El-Gayar, E.S.M. Scanning Electron Microscopy of Fungi Isolated from Some Cake Samples. International Journal of Microbiology and Application 2018 5(3), 50-5

35. McCarthy, M.W.; Kontoyiannis, D.P.; Cornely, O.A.; Perfect, J.R.; Walsh, T.J. Novel agents and drug targets to meet the challenges of resistant fungi. J. Infect. Dis 2017 216(suppl_3), S474-S83. https://doi.org/10.1093/infdis/jix130

36. Ahmad, A.; Khan, A.; Manzoor, N.; Khan, L.A. Evolution of ergosterol biosynthesis inhibitors as fungicidal against Candida. Microb. Pathog 2010 48(1), 35-41. https://doi.org/10.1016/j.micpath.2009.10.001

37. Mapfunde, S.; Sithole, S.; Mukanganyama, S. In vitro toxicity determination of antifungal constituents from Combretum zeyheri. BMC complement. med. Ther 2016 16(1), 1-11. https://doi.org/10.1186/s12906-016-1150-9

38. Paiva, A.D.; de Oliveira, M.D.; de Paula, S.O.; Baracat-Pereira, M.C.; Breukink, E.; Mantovani, H.C. Toxicity of bovicin HC5 against mammalian cell lines and the role of cholesterol in bacteriocin activity. Microbiology 2012 158(11), 2851-2858. https://doi.org/10.1099/mic.0.062190-0

39. Váradi, G.; Tóth, G.K.; Batta, G. Structure and synthesis of antifungal disulfide $\beta$-strand proteins from filamentous fungi. Microorganisms 2019 7(1), 5. https://doi.org/10.3390/microorganisms7010005

40. Butts, A.; Reitler, P.; Ge, W.; Fortwendel, J.R.; Palmer, G.E. Commonly used oncology drugs decrease antifungal effectiveness against Candida and Aspergillus species. Antimicrob Agents Chemother 2018 62(7), 504-18. https://doi.org/10.1128/AAC.00504-18

41. Ngo, H.X.; Tsodikova, G.S.; Green, K.D. A complex game of hide and seek: the search for new antifungals, Medchemcomm 2016 7, 1285-1306. https://doi.org/10.1039/C6MD00222F

42. Butts, A.; Krysan, D.J. Antifungal drug discovery: something old and something new. PLoS Pathog 2012 8(9), 1-3. https://doi.org/10.1371/journal.ppat. 1002870

43. Van der Weerden, N.L.; Bleackley, M.R.; Anderson, M.A. Properties and mechanisms of action of naturally occurring antifungal peptides. Cell. Mol. Life Sci 2013 70(19), 3545-70. https://doi.org/10.1007/s00018-013-1260-1

44. Mannaa, M.; Kim, K.D. Biocontrol activity of volatile-producing Bacillus megaterium and Pseudomonas protegens against Aspergillus and Penicillium spp. predominant in stored rice grains: study II. Mycobiology 2018 46(1), 52-63. https://doi.org/10.1080/12298093.2018.1454015 
45. Du, W.; Yao, Z.; Li, J.; Sun, C.; Xia, J.; Wang, B.; Shi, D.; Re, L. Diversity and antimicrobial activity of endophytic fungi isolated from Securinega suffruticosa in the Yellow River Delta, PLOS One 2020 15(3), 1-18. https://doi.org/10.1371/journal.pone.0229589

46. Nicoletti, R.; Salvatore, M.M.; Andolfi, A. Secondary metabolites of mangrove-associated strains of Talaromyces, Mar. Drugs 2018. https://doi.org/10.3390/md16010012

47. Ferreira, G.F.; Baltazar, L.D.M.; Santos, J.R.A.; Monteiro, A.S.; Fraga, L.A.D.O.; Resende-Stoianoff, M.A.; Santos, D.A. The role of oxidative and nitrosative bursts caused by azoles and amphotericin B against the fungal pathogen Cryptococcus gattii. J. Antimicrob. Chemother 2013 68(8), 1801-1811.

48. Shahina, Z.; El-Ganiny, A.M.; Minion, J.; Whiteway, M.; Sultana, T.; Dahms, T.E. Cinnamomum zeylanicum bark essential oil induces cell wall remodelling and spindle defects in Candida albicans. Fungal Biol. Biotechnol 2018 5(1), 1-16. https://doi.org/10.1186/s40694-018-0046-5

49. Li, Y.; Sun, L.; Lu, C.; Gong, Y.; Li, M.; Sun, S. Promising antifungal targets against Candida albicans based on ion homeostasis. Front. Cell. Infect. Microbiol 2018 8, 286. https://doi.org/10.3389/fcimb.2018.00286

50. Tao, N.; OuYang, Q.; Jia, L. Citral inhibits mycelial growth of Penicillium italicum by a membrane damage mechanism. Food Control 2014 41, 116-21. https://doi.org/10.1016/j.foodcont.2014.01.010

51. Scorzoni, L.; Benaducci, T.; Almeida, A.M.F.; Silva, D.H.S.; Bolzani, V.D.S.; Gianinni, M.J.S.M.; The use of standard methodology for determination of antifungal activity of natural products against medical yeasts Candida sp and Cryptococcus sp. Braz. J. Microbiol 2007 38, 391-7.

52. Leite, M.C.A.; de Brito Bezerra, A.P.; de Sousa, J.P.; de Oliveira Lima, E. Investigating the antifungal activity and mechanism(s) of geraniol against Candida albicans strains. Med. Mycol 2015 53(3), 275-84. https://doi.org/10.1093/mmy/myu078

53. Sharma, A.; Bajpai, V.K.; Baek, K.H. Determination of Antibacterial Mode of Action of Allium sativum Essential Oil against Foodborne Pathogens Using Membrane Permeability and Surface Characteristic Parameters. J. Food Saf 2013 33(2), $197-208$. https://doi.org/10.1111/jfs.12040

54. Amiri Moghaddam, J.; Dávila-Céspedes, A.; Kehraus, S.; Crüsemann, M.; Köse, M.; Müller, C.E.; König, G.M. Cyclopropane-containing fatty acids from the marine bacterium Labrenzia sp. 011 with antimicrobial and GPR84 activity. Mar. Drugs 2018 16(10), 369. https://doi.org/10.3390/md16100369

55. Chen, Y.; Zhou, D.; Qi, D.; Gao, Z.; Xie, J.; Luo, Y. Growth promotion and disease suppression ability of a Streptomyces sp. CB-75 from banana rhizosphere soil. Front. Microbiol 2018 8, 2704. https://doi.org/10.3389/fmicb.2017.02704

56. Mohammedi, Z.; Atik, F. Haemolytic activity of different herbal extracts used in Algeria, Int. J. Pharm. Sci. Res 2014 5, 495-500.

57. Lum, K.Y.; Tay, S.T.; Le, C.F.; Lee, V.S.; Sabri, N.H.; Velayuthan, R.D.; Hassan, H.; Sekaran, S.D. Activity of novel synthetic peptides against Candida albicans. Sci. Rep 2015 5(1), 1-12. https://doi.org/10.1038/srep09657

58. Santussi, W.M.; Bordon, K.C.; Rodrigues Alves, A.P.; Cologna, C.T.; Said, S.; Arantes, E.C. Antifungal activity against filamentous fungi of Ts1, a multifunctional toxin from Tityus serrulatus scorpion venom. Front. Microbiol 20178 , 984. https://doi.org/10.3389/fmicb.2017.00984

59. Thery, T.; Shwaiki, L.N.; O'Callaghan, Y.C.; O'Brien, N.M.; Arendt, E.K. Antifungal activity of a de novo synthetic peptide and derivatives against fungal food contaminants. J. Pept. Sci 2019 25(1), 3137. https://doi.org/10.1002/psc.3137

60. Selitrennikoff, C.P. Antifungal proteins. Appl. Environ. Microbiol $2001 \quad$ (67)7, $2883-94$. https://doi.org/10.1128/AEM.67.7.2883-2894 